\title{
Visión de la vida y la muerte en tres poemas trílcicos de César Vallejo
}

Hay en Trilce (1922) tres composiciones que tienen como tema fundamental distintos aspectos del concepto vallejiano de la vida y de la muerte. Llevan los números LXXV, LXIV y XLIX.

Discutiremos estos poemas en el orden mencionado, aunque éste no representa la posición que ocupan las diferentes piezas en Trilce. Puesto que la colocación de los poemas dentro del volumen no tenía especial importancia para Vallejo (con la posible excepción de Trilce I), no es hacer violencia a la intención del poeta el reagruparlos en la forma aquí propuesta. Los tres poemas reflejan actitudes diferentes, sin otra trabazón entre sí que la personalidad creadora del autor. La nueva serie, sin embargo, hace más fácil aprehender la intención del poeta, pues presenta las composiciones en orden de creciente dificultad. ${ }^{1}$

Nos proponemos determinar los supuestos en que se basa el concepto vallejiano de la existencia, y ver qué relación establece el poeta entre la vida y la muerte. ¿Veía Vallejo la muerte como fin de la existencia o como condición de la vida misma? ¿Tenía el poeta alguna creencia salvadora que le permitiese concebir una supervivencia en el más allá? ¿Admite Vallejo la posibilidad de momentos trascendentes en los cuales el artista logre sobreponerse al continuo del tiempo y a su destino de caducidad?

Veamos ahora el primero de los poemas elegidos.

1 La disposición tipográfica de los poemas es la que tienen en Poesías com. pletas, edición de César Miró, Buenos Aires, Losada, 1949. En el caso de un poema en prosa, como Trilce $L X X V$, diremos "verso" para referimos a un ren. glón, y llamaremos "estrofa" a cualquier grupo de renglones separado de otros grupos por un espacio en blanco, 


\section{Trilce $L X X V$}

1. Estáis muertos.

Qué extraña manera de estarse muertos. Quien. quiera diría que no lo estáis. Pero, en verdad, estáis muertos.

5. Flotáis nadamente detrás de aquesa membrana que, péndula del zenit al nadir, viene y va de crepúsculo a crepúsculo, vibrando ante la sonora caja de una herida que a vosotros no os duele. Os digo, pues, que la vida está en el espejo, y que vosotros

10. sois el original, la muerte.

Mientras la onda va, mientras la onda viene, cuán impunemente se está uno muerto. Sólo cuando las aguas se quebrantan en los bordes enfrentados y se doblan y doblan, entonces os transfiguráis y cre-

15. yendo morir, percibís la sexta cuerda que ya no es vuestra.

Estáis muertos, no habiendo antes vivido jamás. Quienquiera diría que, no siendo ahora, en otro tiempo fuisteis. Pero, en verdad, vosotros sois los cadáve-

20. res de una vida que nunca fue. Triste destino el no haber sido sino muertos siempre. El ser hoja seca sin haber sido verde jamás. Orfandad de orfandades.

$Y$, sin cmbargo, los muertos no son, no pueden ser cadáveres de una vida que todavía no han vivido.

25. Ellos murieron siempre de vida.

Estáis muertos.

Este poema en prosa es un conjunto de proyecciones metafóticas que buscan penetrar el enigma del destino humano. Una primera lectura nos permite ver con relativa facilidad que el poema contiene varias estructuras poéticas plurivalentes en que se hermanan dos procesos paralelos: (a) insistencia en tres grupos de imágenes cósmicas (de luz, movimiento $y$ vibración) y (b) contraste entre la vida consciente y la existencia 
vegetativa, señalándose en particular la ausencia de lo que caracteriza la dinámica del hombre. La mayor parte del poema nos dirá, pues, por qué la vida letárgica es un modo de estar muexto. ${ }^{2}$

(a) Luz. En los versos 6 y 7 se adivina la presencia del sol ${ }^{3}$ en la alusión al espejo la vida está en el espejo, dice el poeta. Vivir es participar de la energía solar o ser reflejo de ella. ${ }^{4}$ El hombre traspasa la frontera del no-ser y se convierte en ente activo en virtud de un contagio cósmico, pero lo hace siempre bajo el signo de la muerte. Su auténtica realidad es, pues, su destino mortal. De aquí que diga el poeta. vosotros sois el original, la muerte.

En Trilce, el espejo es símbolo positivo - fuerza cósmica, hálito suprahumano, amor, o simple presencia reconfortante; 5 en el presente poema es la contraparte de las sombras, las mismas que quedan implícitas en la frase de crepuisculo a crepúsculo, y que constituyen el ámbito del hombre elemental y rutinario.

(b) Movimiento. Fuera del desplazamiento del sol, implícito en la alusión al zenit y al nadir, se representa el dinamismo de la existencia a través de aguas que se quebrantan y doblan (versos 12-13). La vida es un nadar, un "no querer quedarse," como dijo Vallejo en Trilce XLVII. Muy sugestivo es el adverbio nadamente, en que se funden el nadar y la negación nada, esto es, el contraste entre activismo e inercia que da carácter y significado al poema.

En Trilce LXXV aparece el agua como elemento amenazante. Las aguas turbulentas son, como la vida, el elemento móvil y traicionero en que el hombre no halla punto de apoyo; en contraste con ellas están las ondas de la vida rutinaria: Mientras la onda va, mientras la onda viene. Para un espíritu serrano, como era el de Vallejo, el choque de las aguas, especialmente las del mar, debió de configurarse en su mente como símbolo de la existencia humana. No extraña, pues, que sea expresión de desgaste y ariuncio de muerte, tal como se insinúa al final de la tercera

2 Se ha dicho que este poema lo escribió Vallejo en mayo de 1920 al notar la laxitud de la vida provinciana, poco después de volver a Trujillo. Véase: Es. pejo Asturrizaga, Juan, César Vallejo - Iinerario del bombre, Lima, 1965, p. 87.

${ }^{3}$ Debo esta interpretación al Prof. Jorge Medina Vidal.

4 Puede ser que este concepto sea recuerdo de la creencia incaica según la cual el sol es fuente de energía y principio de todo lo creado.

5 En Trilce LXVII se asocia el amor con un espejo: pensamos que vendría el gran espejo ausente; en Trilce VIII se intuye la posibilidad de un algo que permite a un mortal sobrepasar los límites de su finitud: margen de espejo ba brát donde traspasaré mi propio frente. 
estrofa. Los bordes enfrentados no son dos lados, opuestos el uno al otro, sino todo aquello que es barrera y se opone al embate del mar. ${ }^{6}$

(c) Vibración. El hombre vivo, dice Vallejo, es el ser sensible. El "muerto" es, por el contrario, el que presencia el dolor humano, representado aquí por la berida del verso 8 , y no lo siente. Sólo en la agonía llega éste a comprender la existencia de la sexta cuerda. Los "muertos" han vivido con un instrumento vibrador -su propio ser- que está representado aquí por una guitarra. Sólo en presencia de la muerte descubren tales hombres la cuerda intocada. El no haber jamás vibrado esa cuerda es como no haber vivido nunca la vida en su real y viva entereza ${ }^{7}$

La vibración aparece en el poema en otras formas. La membrana del verso 5 se refiere a la piel que cubre un parche o tambor, como el que se adivina en Tricle $X L I,{ }^{8}$ y que aquí es el elemento sensible en que repercute el dolor del hombre. Si la membrana péndula es la atmósfera vital, la caja sonora es la humanidad, en cuyo seno flotan "nadamente" los hombres que viven ajenos a toda conmoción espiritual. Nada de esto es mera especulación, pues el poeta mismo emplea el verbo vibrar en el verso 7 .

Hasta aquí hemos señalado tres contrastes que representan en el poema la vida y la muerte: (a) luz y sombras; (b) turbulencia y quietud; (c) vibración y mudez. Detrás de estas contraposiciones se advierte una concepción cíclica de la existencia, un eterno retorno, que el poeta expresa indirectamente:

\section{5. aquesa membrana... viene y va}

Este retorno trae a la mente el concepto nietzscheano del mundo, con el cual concuerda Vallejo enteramente. La vida consciente es un estar dentro de un patrón eterno de alternancias, a la par que la vida vegetativa es no tener conciencia de esta voluntad cósmica.

También está subentendido en T'rilce LXXV el continuo temporal. Lo hallamos en varias sugerencias poéticas, algunas de ellas muy sutiles. A parece primero en los versos 6 y 7: viene y va de crepúsculo a crepuiscu-

6 La lucha simbólica de agua y tierra se halla también en Trilce XLVII. Este tema lo hemos discutido en otro trabajo que está al presente en vías de publica. ción: "Roca y mar en dos poemas de César Vallejo".

7 La cuerda intocada podría asociarse al llamado "sexto sentido", que nos comunica todo lo que no captan las cinco vías perceptivas del cuerpo humano.

8 Dice este poema: En tanto el redoblante policiall... se desquita y nos fun. de a palos, d dale y dale,/ de membrana a membrana, tas / con/ tas./ 
lo; vuelve a insinuarse en el mientras del verso 11 , y se hace por fin patente hacia el final en el abora y el otro tiempo, de los versos 8 y 9 . El transcurso del tiempo está también subentendido en esa vida que nun. ca fue y en el no haber sido. Ninguna duda cabe, pues, de que el vivir es para Vallejo estar inserto en el continuo del tiempo.

En resumen, el hombre es mortal en dos sentidos: (1) por ser originalmente, como hemos visto, concreción de mortalidad (verso 10), idea reforzada por el verso 25 , en el cual la vida se concibe como causa del morir, y (2) por sustraerse al dinamismo del cosmos, con la consiguiente merma de su hombredad (verso 12). Triste destino, este último - nos dice el poeta- aun siendo un modo de evitar la angustia del diario vivir. Vallejo cree, pues, que el hombre ha de elegir el camino de la vida consciente, aun sabiendo que lleva inevitablemente al dolor.

La primera mitad del poema es expositiva (versos 2-10); las dos estrofas siguientes (versos 11-22) son de tono reflexivo, pero el final es una dubitación que nos hace entrar en un ámbito paradojal. La estructura intelectual vallejiana típica es, como la presente, la que llevh a la duda. Ése es el sentido de la suposición implícita en cudquierd diría y en la contraposición establecida por el sin embargo, del verso 23. Estas expresiones añaden al poema, primero, una incertidumbre y, luego, una reafirmación: Estáis muertos. Todo esto demuestra que la disposición de las partes constitutivas del poema responden a un movimiento interior en que se entrelazan intuiciones, enfoques aproximativos, racionalizaciones y dudas.

Este tipo de estructura denotativa, que se halla en varios poemas trílcicos, es uno de los recursos de que se valió Vallejo para hacer partícipe al lector de los distintos momentos gestativos de su creación. El poema no se da como un todo ya elaborado sino como un proceso de configuración, con avances y retrocesos, dudas y certezas.

Si apuramos un poco más el análisis, vemos que el poema es un conjunto de intuiciones y una meditación. Por esto, Trilce $L X X V$ es búsqueda y aseveración al mismo tiempo. En esta doble urdimbre se enlazan imágenes de dos mundos: el exterior (cielo, tierra, aguas, costas) y el interior (dolor, transfiguración, ser). Hay, pues, en el poema, grandeza espacial y hondura psíquica, que trasmiten al lector un aliento cósmico y un íntimo sentido de la vida, todo ello expresado en lenguaje taumatúrgico. La voz del poeta creador resuena en muchas ocasiones como la de un profeta. Así lo demuestra el empleo de la segunda persona del plural en trece ocasiones estáis muertos, a vosotros no os duele, os digo, 
vosotros sois el original, en otro tiempo fuisteis, etc. El formalismo de estas construcciones está muy en armonía con la solemnidad del poema.

Tricle LXXV se destaca por su estilo reiterativo: el "estar muerto," que abre y cierra el poema sirviéndole de marco, se repite, con algunas variantes, un total de seis veces, por lo cual el poema se desenvuelve como insistencia, como expresión de una idea fija. A este psicologismo poético se suma el tono sentencioso de oraciones apodícticas sois los cadáveres de una vida que nunca fue; vosotros sois el original, la muerte, etc. En el fondo de estas afirmaciones, y de otras, se advierte, además, un contraste de conceptos a través de los verbos "ser" y "no ser," o bien, "ser" y "estar," pero sin que por esto se desvirtúe el clima poético, el cual se mantiene a lo largo de toda la composición.

En suma, Trilce LXXV es un poema de refrenada emotividad y de vuelo filosófico, cuya estructura total y lenguaje están en perfecta consonancia con la intención que en él se encierra. Su contenido nos lleva a preguntarnos si la vida consciente contiene, según Vallejo, una recompensa para el que decide no evadirse de su destino humano. La respuesta la hallaremos en el segundo poema de nuestra serie:

\section{Trilce LXIV}

1. Hitos vagarosos enamoran, desde el minuto montuoso que obstetriza y fecha los amotinados nichos de la atmósfera.

Verde está el corazón de tanto esperar: y en el

5. canal de Panamá ¡hablo con vosotras, mitades, bases cúspides! retoñan los peldaños, pasos que suben pasos que baja-

n.

$\mathrm{Y}$ yo que pervivo,

10. y yo que sé plantarme.

O valle sin altura madre, donde todo duerme horrible mediantinta, sin ríos frescos, sin entradas de amor. Oh voces y ciudades que pasan cabalgando en un dedo tendido que señala a calva Unidad. Mien- 
15. tras pasan, de mucho en mucho, gañanes de gran costado sabio, detrás de las tres tardes dimensiones
Hoy
Mañana
Ayer
(No, hombre!)

Trilce $L X I V$ es un poema más difícil que el anterior porque contiene conceptos poéticos complejos vertidos en formas retorcidas. Hay, además, saltos conceptuales entre estrofas y una progresiva condensación del pensamiento poético que culmina en un balbuceo final y una enigmática protesta. Fuera de contener símbolos de significación muy especial y elaboraciones poéticas de conceptos, halla el lector oscuras referencias a cosas y personas, amén de no pocas abstracciones, todo ello en función desrealizadora y generalizante. Detrás de este apretado nudo palpita el drama particular de Vallejo, el cual está transformado en materia poética, excepto al final, como luego veremos.

En Trilce LXIV se configura una meditación sobre dos determinantes de la condición humana - la espacialidad y la temporalidad-, dándose éstas como razón de las limitaciones del hombre y de su destino de finitud. Así nos lo dicen las muchas alusiones a entidades espaciales (mitades, bases cuispides) y a dimensiones temporales, como las que aparecen en el verso 16, separadas por grandes espacios en blanco:

Hoy Mañana Ayer.

Ningún pensamiento parece haber obsesionado tanto a Vallejo, en los años que van desde la composición de Los beraldos niegros hasta Trilce como la conciencia de las limitaciones humanas. El hombre es ente ca. paz de desear lo absoluto - dice Vallejo-, pero ha de vivir entre relatividades, en una como agonía espiritual motivada por su propia naturaleza. Esta agonía no es el miedo de un Rubén Darío ante lo ignoto, ni la trémula expectación de un Nervo, sino una dolorida certeza de la finitud del hombre. La persistencia de esta preocupación vallejiana la atestiguan diferentes poemas y piezas en prosa que contienen referencias a lindes, linderos, limites y limitaciones, o a equivalentes, como frente o fronteras, la misma idea aparece implícita en el verbo limitar. Veamos algunos ejemplos:

¡Ah, mano que limita, que amenaza

tras de todas las puertas, y que alienta

en todos los relojes, cede y pasa! 


\section{("Unidad," Los heraldos negros)}

Mas, ¿no puedes, Señor, contra la muerte, contra el límite, contra lo que acaba?

$$
\text { ("Absoluta," Los beraldos negros) }
$$

donde traspasaré mi propio frente

$$
\text { (Trilie VIII) }
$$

Vuelve la frontera a probar las dos piedras que no alcanzan a ocupar una misma posada a un mismo tiempo.

(Tricle LIII)

La Muerte está soldando cada lindero (Trilce $L V$ ) ...por este camino traspasaba las lindes del amor y del bien...

("Liberación," Novelas y cuentos completos, p. 40)

No parece aventurado suponer que Vallejo concibió la condición mortal y finita del hombre como extensión de un concepto bíblico repetido en el hogar de su infancia quizá muchas veces: el hombre arrojado del Edén expía el pecado original en su naturaleza finita. Nada hay en el poema que sugiera la raíz religiosa recién insinuada, pero hacemos nuestra afirmación apoyándonos en un pasaje de El tungsteno, novela vallejiana publicada en Madrid, en 1931. Dicho pasaje repite casi textualmente otro inserto en el relato "Sabiduría," publicado en el No 8 de Amauta (1927), según la noticia introductoria del volumen Novelas y iuentos completos (Lima, 1967). A juzgar por las fechas, es probable que dicho pasaje sea una ampliación en prosa de los conceptos básicos del poema que aquí estudiamos. Según Espejo Asturrizaga, el poema data de $1919 .{ }^{9}$ El relato "Sabiduría" y la novela El tungsteno son posteriores.

Antes de analizar Trilce LXIV, fijemos la atención en algunas partes del relato, subrayando aquellas frases que luego nos servirán para en. trar en la interioridad del poema. Al describir una visión mirífica de un enfermo, dice Vallejo:

Pero un sentimiento extraordinario de algo jamás registrado en su sensibilidad, y que le nacia del fondo mismo de su ser, le anunció que se hallaba en presencia del Señor. Tuvo entonces tal cantidad de luz en su pensamiento que lo poseyó la visión entera de cuanto fue y será, la conciencia integral del tiempo y del espacio, la ima-

9 Op. cit., p. 113. 
gen plena y una de las cosas, el sentido eterno y esencial de las lindes... En su ser se había posado una nota orquestal del infinito, a causa del paso de Jesús y su divino oriflama por la antena mayor de su corazón. Luego volvió en sí, y al sentirse apartar de delante del Señor, condenado a errar al acaso, como numero disperso, zafado de la armonía universal por una gris e incierta inmensidad, sin alba ni poniente, un dolor indescriptible y nunca experimentado en su vida, le colmó el alma hasta la boca, ahogándole...

Refiriéndose luego a la potencia del ser infinito, exclama el enfermo haciendo memoria de cuanto perdió el hombre al quedar inserto en la finitud:

¡Cuando pude cercenar las cosas por la mitad, tomarme solo las caras y volver a sacar de los sellos otras caras y otras más hasta la muerte! ¡Cuando pude borrar de una sola locura los puentes y los istmos, los canales y los estrechos, a ver si mi alma se quedaba quieta y contenta, tranquila y satisfecha de su isla, de su lago, de su ritmo!

$Y$, por fin, dando a entender claramente el sentido teológico de lo absoluto, menciona Vallejo la raíz bíblica de sus elucubraciones:

¡Señor! Yo fui el pecador y tu pobre oveja descarriada. ¡Cuando estuvo en mis manos ser el Adán sin tiempo, sin mediodía, sin tarde, sin noches, sin segundo día ¡Cuando estuvo en mi mano embridar y sujetar los rumores edénicos para toda la eternidad y salvar lo Cambiante en lo Absoluio! ¡Cuando estuvo en mis manos redlizar mis fronteras garra a garra, pico a pico, guija a guija, manzana a manzana!... ¡Yo pude ser solamente el óvulo, la nebulosa, el ritmo latente e inmanente, Dios!10

Para Vallejo absoluto e infinito son términos idénticos; ambos expresan conjunción de tiempos, unicidad espacial, exclusión de todo cambio o fraccionamiento, de toda limitación o dependencia. ${ }^{11}$ En contraste con esta perfección suprema está la esfera de lo humano con todas sus relati-

10 Los pasajes citados están en Novelas y cuentos completos, Fco. Moncloa editores, Lima, 1967, pp. 125-127.

11 Esta idea está nítidamente expresada en "Absoluta" (Los beraldos negros): Oh unidad excelsa! Oh lo que es uno/ por todos! Amor contra el espacio y con. tra el tiempo!/ Un latido único de corazón;/ un solo ritmo: Dios! 
vidades, dualismos y constante devenir. La vida del hombre es conciencia de imperfecciones y sed de infinito.

En el fondo del pensamiento vallejiano está, pues, la irreconciliable oposición entre lo humano y lo divino. Ser hombre es ser imperfecto, y vivir es tener conciencia de limitaciones. De aquí que, con profundo dolor, señale el poeta en "Espergesia," el último poema de Los beraldos negros, la imperfección de nuestro medio ambiente y el misterio de nuestra circunstancia vital:

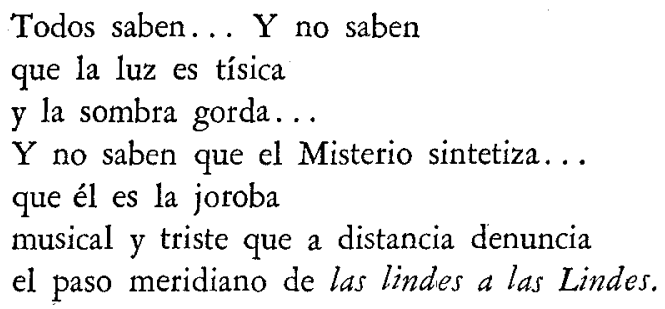

Trilce LXIV es una dramática representación poética de la vida como un sueño de perfección irrealizable. Tal como en "Espergesia," hay en Trilce LXIV un drama espiritual. Para aclarar el alcance de ese drama señalemos ahora las coincidencias que hay entre el significado de las citas en prosa y el sentido intimo del poema. Podría afirmarse que en el relato están las ideas básicas del tema, y en el poema, la experiencia poética de las mismas. Relato: aproximación conceptual. Poema: intuición del drama de la existencia. El hombre del relato es, en el poema, un demiurgo cuya visión va más allá de los confines de la razón.

El poema se abre con el despertar del ser a la vida terrenal, como bien lo sugiere el neologismo "obstetrizar" del verso 2. Inserto en el drama cósmico, halla el hombre bitos vagarosos, esto es, solicitaciones imprecisas que van a constituir las metas engañosas de su existencia.

El poema diseña luego un ambiente de indefinición en que nada está referido a una persona en particular; el verbo enamoran, por ejemplo, tiene un objeto directo indefinido, que alude a "cuantos nacen." Esta concepción genérica le da al poema un tono filosófico desde el principio.

El poema menciona a continuación un "minuto montuoso," que es el momento álgido del nacer y que encierra ya las nociones de tiempo (minuto) y de espacio (monte). Los hombres ingresan en la vida terrenal tras un acto de rebeldía y se integran a un mundo inarmónico bajo el signo de la muerte; son, pues, los amotinados nichos de la atmósfera. ${ }^{12}$

$12 \mathrm{El}$ concepto del nacer como rebeldía o facción aparece también en el poema 
Llegan, además, al mundo con una fecha (verso 2). Vivir es igual a ser en el tiempo.

La segunda estrofa lleva envuelto un salto temporal. El hombre vive ahora apoyado en una esperanza imposible, la de sobrepasar su condición humana, como lo indica el verso 4 , que asocia un adjetivo de coloración

la esperanza: Verde está el corazón de tanto esperar. Esta línea recuerda la denominación popular del verde como color de esperanza. El verde sugiere también una imposibilidad de maduración.

Viene ahora un segmento que parece ser una acumulación caótica de cosas y acciones humanas contradictorias. Este caos es más aparente qué real. Los versos 4-8 son todos alusiones poéticas a la realidad espacial de nuestro mundo, realidad finita, que tiene comienzo y fin, forma variada y dimensión.

$4 . \quad \quad \ldots y$ en el

5. canal de Panamá ¡hablo a vosotras, mitades, ba-

6. ses cúspides! retoñan los peldaños, pasos que suben

7. pasos que baja-

8. $\mathrm{n}$.

Aquí es necesario un paréntesis. En contraposición con la materia en el espacio, siempre descoyuntada y dimensional, concibe el poeta, po: inferencia, la infinitud, que es una y múltiple a la vez, que no está sujeta a ninguna categoría espacial. El hombre ansía tener --según el relato"la imagen plena y una de las cosas." Ahora bien, tras de lamentar el haber sido arrojado del seno de Dios y ser ente espacial, el personaje de "Sabiduría" deplora su desdicha refiriéndose a la fragmentación y discontinuidad de la materia:

¿Cuando pude borrar de una sola locura los puentes y los istmos, los canales y los estrechos...! (El subrayado es nuestro).

Esta última cita explica con absoluta nitidez el sentido de la frase el canal de Panamá - símbolo de ruptura espacial. En cuanto a las formas y partes de los versos 5-6 (mitades y bases cuispides), representan éstas la ausencia de unidad, la proliferación confusa y antitética. El mundo es y será siempre -dice el poeta- el reino de lo múltiple y discontinuo, en donde la materia está organizada en escalas contrapuestas y de

siguiente. Tal rebeldía bien puede ser reflejo de la desobediencia de Adán y, por ende, de todos sus descendientes (Génesis, Cap. 3). 
estructura inconexa. Esto último lo expresa el poeta al desgajar una consonante final y hacer de ella un "verso": pasos que baja-/ $n$.

Los versos finales de la segunda estrofa implican una personalización del vuelo poético a través de dos enunciados que valen por exclamaciones: $Y$ yo que pervivo/ y yo que sé plantarme. Bien mitados, estos versos llevan a una pregunta: "¿Qué será de mí —parece decirnos el poeta- condenado como estoy a seguir viviendo en el tiempo (pervivo) e inclinado siempre a enraizarme en la tierra (sé plantarme)"?

El paisaje del hombre iluso, el de rios frescos y entradas de amor (¿recuerdo del Paraíso?) ha sido una vana esperanza. Por eso lamenta el poeta las consecuencias de su condición humana en dos exclamaciones de profunda desilusión: $O b$ valle ... Ob voces y ciudades... La tercerá estrofa traduce, como se ve, un estado depresivo, una distensión del espíritu. El poeta ve la realidad terrenal como mísera planaridad, afeada por su falta de luz e inanición: Ob valle sin altura madre, donde todo duerme horrible mediatinta. La "altura madre" ausente es la presencia divina, la misma que aparece en la visión del relato, y la "horrible mediatinta" es la luz tísica de Espergesia. El cosmos no contiene, pues, una idea de Dios que respalde la existencia objetiva - concepto cartesiano--, ni es jerárquico o armónico, como lo concebía Leibnitz. En él todo está en tinieblas y va a un mismo destino, a una calva Unidad, que es la muerte, la Nada. Allá van los hombres (voces) y sus creaciones (ciudades) porque ese es el designio del mundo, designio implicito en el dedo tendido del verso 14 , que sugiere el triste destino último de todo lo creado. ${ }^{13}$.

A medida que el poema se acerca a su fin, aumenta aún más la desilusión del poeta al imaginarse un desfile de seudosabios (gañanes ${ }^{14}$ de gran costado sabio) que viven, por desgracia, en una serie temporal, y, lo que es peor, en una serie trastocada: Hoy Mañana Ayer.

El poeta nos dice aquí que el tiempo (con sus tardas dimensiones) nos consume con lento arrastre y grandes espacios en blanco, tales como los que sugiere la disposición tipográfica misma. Pero esta serie ilógica prefigura también la muerte, pues se da ésta en un futuro que ya es un ayer. Queda así confirmada la idea sugerida en el verso 2 por un nicho ya preexistente al llegar el hombre al mundo. El nicho es, en último

13 La imagen del dedo la hallamos también en el tercer poema de nuestro grupo: ductores indices grotescos (Trilce XLIX).

14 Interpretamos la palabra gañanes en sentido peyorativo, tal como obreros, en Trilce LXVI: cantores obreros redondos... La frase gran costado sabio parece ser, por otra parte, una alusión a los especialistas. 
análisis, el hombre mismo, porque su ser y su destino de caducidad son una y la misma cosa.

Termina el poema con una exclamación final que es una protesta y quizá también una ironía: (No, hombre!). El hombre pensante que se alberga en la persona del poeta no se resigna a ser objeto espacial y temporal. Su anhelo es ser, como dice el relato, "Adán sin tiempo, sin mediodia, sin tardes, sin noches..." Por esto las palabras del poema parecen decir: “¡No! ¡No puede ser tan mezquino el destino del hombre!" También es posible que el poeta desee negar, con un autorreproche, cuanto su imaginación ha forjado durante el trance poético. Cualquiera que sea el significado que se le atribuya al final, éste constituye un juicio intelectual que está fuera del ámbito poético del poema. El cambio de intención lo confiesa el propio autor al poner la expresión entre paréntesis. Éste no es el caso de las tres construcciones regidas por un sujeto en primera persona: bablo con vosotras (verso 5); $Y$ yo que pervivo; yo que sé plantarme (versos 9 y 10). Ninguna de éstas es una referencia al yo empírico, al hombre cotidiano, sino al poeta creador, el ente que estructura el poema. Dicho en otras palabras, en los tres casos mencionados -en contraste con la exclamación final- no hay anécdota sino una experiencia poética.

Dejando a un lado la exclamación final, se ve que el poema tiene tres momentos:

1) inserción del hombre en el tiempo y el espacio (estrofa 1);

2) desilusión del hombre ante un mundo plural y discontinuo (estrofa 2);

3) lamentación del hombre acerca del destino de todo objeto terrenal (estrofa 3).

El final del poema, exceptuando la exclamación del verso 18, es todo de sentido negativo. Así lo acusan las palabras y frases peyorativas que en él figuran: calva, de mucho en mucho, tardas y gran. ${ }^{15}$

Trilce LXIV es un poema centrado en un solo motivo: el drama existencial, pieza en tres actos y un epílogo: nacer (estrofa 1), vivir (estrofa 2) y morir (estrofa 3 ). Todo el poema tiene un mismo tono de descngaño. El creador contempla el drama sabiéndose parte de él. Esta doble postura de actor y contemplador omnisapiente da a la composición do-

15 El adjetivo gran aparece varias veces en 'Trilce con sentido peyorativo: el gran colapso (V); un gran caldo de alas (XLIX); la gran boca que ba perdidfo el babla (LVI); tu gran plumaje (XL). 
ble cariz, pues representa la existencia, a la vez que expresa un dolorido sentir.

La nota emocional, como en tantas otras composiciones trílcicas, se insinúa sólo a través de la forma interior del poema. El dolor vallejiano está muy lejos de ser una histriónica protesta, pero no es por ello menos hondo ni menos sincero. Ante lo irremediable el ser vivo puede sólo exclamar: No, hombre! Este brevísimo epílogo cierra el poema con absoluta finalidad, representando al ente humano abatido y horrorizado ante la realidad de su condición terrenal.

Esta misma nota derrotista, pero elevada a un plano de mayor agonismo, la hallamos también en el último de los poemas elegidos.

\section{Trilce XLIX}

1. Murmurado de inquietud, cruzo, el traje largo de sentir, los lunes de la verdad.

Nadie me busca ni me reconoce,

5. y hasta yo he olvidado

de quién seré.

Cierta guardarropía, sólo ella, nos sabrá

a todos en las blancas hojas

de las partidas.

10. Esa guardarropía, ella sola, al volver de cada facción, de cada candelabro ciego de nacimiento.

Tampoco yo descubro a nadie, bajo

15. este mantillo que iridice los lunes de la razón;

y no hago más que sonreír a cada púa de las verjas, en la loca búsqueda del conocido.

20. Buena guardarropía, ábreme tus blancas hojas; quiero reconocer siquiera al 1 , quiero el punto de apoyo, quiero saber de estar siquiera.

25. En los bastidores donde nos vestimos, 
no hay, no Hay nadie: hojas tan sólo

de par en par.

Y siempre los trajes descolgándose

por sí propios, de perchas

30. como ductores índices grotescos,

y partiendo sin cuerpos, vacantes,

hasta el matiz prudente

de un gran caldo de alas con causas

$y$ lindes fritas.

35. Y hasta el hueso!

Aunque distorsionado e ilógico a primera vista, Trilce XLIX tiene una coherencia interior innegable. Por encima del drama personal, hay una teoría del vivir desarrollada dentro de un clima poético de desaliento que, poco a poco, se transforma en un ambiente de tremenda tensión. psíquica. Se observa, además, una clara alternancia de sujetos en escala cada vez más impersonal. En la primera estrofa el sujeto es yo; en la segunda, se destaca un nosotros; en la tercera y la cuarta, reaparece el yo, pero al final se vuelve al punto de vista colectivo (nos vestimos), para hacer desembocar, for fin, el pensamiento en una conceptualización simbólica exenta de connotaciones particularizantes. Este tipo de enfoque múltiple es común en la poesía trílcica. Vallejo reúne diferentes puntos de vista en una misma concepción y articula así una visión plural en que se complementan e integran, por influencias recíprocas, diferentes planos conceptuales, dentro de un esquema cada vez más abstracto y generalizador: el yo y el nosotros no son sino escalones de ascensión a un mundo de verdades últimas. Veamos ahora en qué consisten tales verdades, examinando primero los supuestos que a ellas conducen.

En Trilce XLIX están implícitos dos conceptos fundamentales. El primero de éstos es el extrañamiento del yo, que hallamos sugerido por varios verbos:

5. he olvidado, de quién seré

22. quiero reconocer siquiera al 1

23. quiero.../ saber de estar siquiera

Estas citas apuntan todas a una misma idea: el hombre pasa por la vida como un enajenado, sin entender el mundo que le rodea ni su propio yo. A las sombras exteriores e interiores se añade la imposibilidad de comunicación espiritual: 
4. Nadie me busca ni me reconoce

14. Tampoco yo descubro a nadie...

El poema dramatiza aún más la miseria del hombre estableciendo un contraste entre esencia y existencia a través de los verbos ser y estar; aquél es sinónimo de vida espiritual y éste, simple subsistir en el espacio. Esta idea que está presente en los dos poemas anteriores, como ya hemos visto, aparece aquí en dos lugares:

5. y hasta he olvidado de quién seré.

23. ...quiero saber de estar siquiera.

Incapaz de comprenderse a sí mismo y convertido en objeto de crítica (Murmurado de inquietud), el yo del poema desea saberse existente al menos como ente físico, aunque sea en un mundo vacío; éste se representa aquí con patético desconsuelo mediante una oración reiterativà en que aparece una mayúscula:

\section{6. no hay, no Hay nadie...}

No se trata aquí de un solipsismo, puesto que el poeta ha quedado reducido a la categoría de ser inconsciente. Esta degradación no es el resultado de una falla de la voluntad, ni del simple azar. Su causa primaria es la condición humana misma, pues el hombre llega a la vida incapacitado para ver: es ciego de nacimiento ${ }^{16}$ (verso 13). Tan menguados principios están sugeridos por el bautismo, ceremonia en que la invidencia de la vida la expresa un candelabro no encendido (versos 12-13). Además, el comienzo del vivir está representado como una facción, esto es, una rebeldía. El hombre, arrojado del seno de Dios, está condenado, como dice el relato "Sabiduría," "a errar al acaso, como número disperso, zafado de la armonía universal." 17 La misma idea de facción, o motín, aparece en Trilce LXIV (versos 2-3), como ya indicamos en páginas anteriores.

La entidad más importante del poema es la guardarropía. Conviene observar aquí la confluencia de imágenes: la guardarropía es, al mismo tiempo, cosa y ser activo; en ella habrá de quedar el traje con que hicimos un papel en la vida, pero ella es, al mismo tiempo, una inexorable

16 Esta misma idea está presente en Trillce XLVII: Los párpados cerrados, como si, cuando nacemos, siempre no fuese tiempo todavía.

17 Novelas $y$ cuentos completos, p. 125. 
"contadora," en cuyo libro de blancas hojas se asientan las partidas de nacimiento, que son también las de la muerte. El partir es comienzo y principio de un fin. En un sentido más amplio la guardarropía es la matriz cósmica de donde partimos, ${ }^{18}$ matriz que conoce a cuantos han nacido (versos 7 y 8). Ella encierra el sarcasmo de la vida, pues es la fuente original y también la Nada a donde llegamos al terminar nuestros "falsos trajines."

El segundo concepto fundamental es el anhelo de extinción. El hombre es como un ser deambulante que no llega siquiera a una integración del yo (quiero reconocer siquiera al 1). Tales son su desorientación y su angustia que sólo ansía la muerte, a quien llama como recurso final: Buena guardarropia, ábreme/ tus blancas bojas (versos 20 y 21). Por estar implícito aquí el tema de la madre, se encierra en estas palabras un complejo de dependencia psicológica, el cual explicaría el tono rogativo de estos versos. El poema contiene, en suma, la queja de un hombre maduro y también algo así como el ruego de un niño desvalido. $Y$ ¿qué es esto sino la esencia misma del yo creador vallejiano, en el cual es. tán siempre hermanados el hombre y el niño?

Por todo lo dicho se comprenderá por qué no concordamos con el Sr. Espejo Asturrizaga al destacar el sentido autobiográfico del poema. ${ }^{19}$ Basta observar que el poeta no ha insistido en el trasfondo sentimental sino en las ropas que lleva el hombre, concebidas ya como envoltura exterior con que cubrimos nuestra humanidad, o como resto mortal de lo que fuimos - trajes vacantes que se descuelgan y siguen la senda indicada por los ductores índices grotescos. Se notará que la idea de encubrimiento se repite tres veces: primero, al mencionarse el traje largo de sentir (verso 2), luego, a través del mantillo que iridice los lunes/ de la razón (versos 15 y 16) y, por último, en la alusión a los trajes vacantes ya mencionados. ${ }^{20}$ Lo que encubre nuestra humanidad es, pues, de especial importancia para Vallejo. Todos nos echamos encima un disfraz - dice el poeta- cuando racionalizamos el sentido de nuestra vida los lunes de la verdad (que son los lunes de la razón), ocultando así nuestro verdadero ser (versos 2 y 3 ). De igual modo se engañan los demás. $Y$ con ello la vida cobra otro aspecto y da la falsa impresión de ser iridis-

18 Esta matriz sería la misma que aparece aludida en "Espergesia": el claustro de unn silenciol que babló a flor de fuego. Sobre este punto véase: Larrea, Juan, César Vallejo o Hispanoamérica en la cruz de su razón, Córdoba (Argentina), 1957, p. 68.

19 Op. cit., p. 119. Mucho más acertada es la opinión del Sr. Saúl Yurkievich, quien ve en la guardarropia un anuncio de muerte. Véase: "En torno de Trilce", Revista peruana de cultura, diciembre 1966, Nos. 9-10, p. 86.

20 Sobre los posibles significados de vacantes, véase: Larrea, Juan, "Considerando a Vallejo", Aula Vallejo 5-6-7, Córdoba (Argentina), 1967, pp. 194-195. 
cente. El hombre vive, pues, de un engaño, el de su envoltura exterior que, al final, se reconoce como una simple cáscara perecedera.

La idea central de ser el hombre un actor en el teatro de la vida explica por qué escogió Vallejo los sustantivos bastidores y guardarropía para sugerir el comienzo y el fin de una "actuación;" en los bastidores en que nos vestimos para hacer nuestro papel quedan después los trajes vacíos, para ir luego a la muerte. El verbo descolgándose del verso 28 , es, pues, una referencia más al viaje postrero. Han desaparecido los cuerpos y también las falsas envolturas. La comedia del vivir ha terminado. Sólo queda la nada.

Esta visión pesimista de nuestro fin terrenal cobra especial dramaticidad en algunos pasajes de gran valor plástico. Vallejo tenía una mente gráfica que le permitía ver detalles lineales o de forma: en el verso 11 se dramatiza el aspecto desgarrador de la vida en la alusión a cada prial de las verjas. El vacío está, a su vez, plásticamente representado en las bojas ... de par en par, de los versos 26 y 27 . Y la visión onírica de la última estrofa se apoya en una imagen gráfica de extraordinaria fuerza: perchas/ como ductores indices grotescos, que apuntan a la Nada con el gesto imperial de un director de escena.

Trilce XLIX está transido de derrotismo. Podría decirse que la intención del poeta no es otra que ir mermando dignidad al hombre desde el comienzo hasta el último verso. Este proceso de "reducción trágica" consta de las siguientes etapas:

1. Desarmonía exterior e interior: Murmurado de inquietud.

2. Encubrimiento del yo: cruzo/ el traje largo de sentir.

3. Pérdida de identidad social: Nadie ... me reconoce.

4. Inconciencia del yo: ... be olvidado/ de quién seré.

5. Insuficiencia inicial del hombre: ciego de nacimiento.

6. Ausencia del lazo cordial: la loca búsqueda/ del conocido.

7. Falta de un asidero espiritual: quiero el punto de apoyo.

8. Ingreso en la nada: no bay/ no Hay nadie; bojas tan solo...

9. Desintegración de las falsas exterioridades: trajes descolgándose.

10. Degradación última: un gran caldo de alas con causas/. y lindes fritas.

Este poema, como el anterior, está concebido en tres tiempos, dentro de un esquema de progresiva intensidad: las tres primeras estrofas son un recuento de desvalorizaciones; ellas nos dicen todo lo que el hombre no es. La estrofa 4 es un angustioso llamado final a la muerte en que se 
encierran tres mínimas peticiones últimas, todas ellas expresadas con un mismo verbo: quiero reconocer siquiera al 1,/ quiero el punto de apoyo quiero/ saber de estar siquiera. ${ }^{21}$

En contraste con estos anhelos, se juntan en la última estrofa las apariencias y las esencias, para condenarlas a una gradual extinción. Se ha iniciado la partida mencionada en el verso 9; al final del poema se vuelve a insinuar esta idea al presentarse los trajes partiendo sin cuerpos (verso 31), en viaje hacia el exterminio, representado aquí por un gran caldo (verso 33) en que todo se mezcla y desintegra a fuego lento (matiz prudente). En él hallaremos el disfraz del hombre, esto es, su caparazón exterior, como también sus anhelos (alas), sus motivaciones (causas) y sus frustraciones (lindes) y hasta su andamiaje óseo. La vida no es sino un lento deshacerse, y la mucrte, un proceso final comparable a la preparación de un modesto potaje, al que se le aplica irónicamente un adjetivo de grandeza. A la indignidad de la muerte misma se suma el peso del adjetivo fritas, que lleva la "reducción trágica" a su más infimo extremo. Ese adjetivo es referencia culinaria y también aseveración peyorativa, por traer a la mente un coloquialismo degradante: ¡estamos fritos! 22

El término de la existencia nos lo da dramáticamente una expresión críptica final: $Y$ basta el bueso! Esta exclamación ambivalente no sólo se refiere a nuestra armazón interior, que también será parte del "gran caldo" en que se deshace la realidad humana, sino que, además, alude a un dolor máximo, como el que produce una herida profunda. ${ }^{23}$

Examinado el poema en su totalidad, se observa que está compuesto de numerosas aseveraciones separadas por rupturas intencionales, como lo indica la disposición misma de los versos. Esas rupturas pueden ser simples espacios de tiempo o vacíos ideológicos, esto es, ausencia de palabras exigidas por el sentido. Veamos un ejemplo:

21 Algo parecido hizo Neruda en El bondero entusiasta, libro juvenil posteriot a Trilce. Lo que en Vallejo es ruego, en Neruda es afirmación y exigencia: pero quiero pisar más allá de esa huella/ pero quiero voltear esos astros de fuego/... quiero alzarme en las últimas cadenas que me aten.

22 El empleo de imágenes degradantes al fin de una estrofa es común en los versos de Vallejo. En Trilie LIX, por ejemplo, se asocia la muerte a un corral, y en Poemas humanos se representa el colapso del hombre aludiendo a la descomposición de su cuerpo: Más valdría, en verdad, que se lo coman todo, desde luego! (Edición de César Miró, pp. 128 y 216 respectivamente).

${ }_{23}$ La expresión "hasta el hueso" la usa también Vallejo para indicar aquello que queda normalmente oculto: "( sus labios) no se entreabrían... por miedo a desnudarse hasta el hueso", Véasese: "Cera", en Novelas y cuentos completos, p. 72. 
1. Murmurado de inquietud, cruzo, el traje largo de sentir, los lunes de la verdad.

He aquí dos versos "largos" y un pie quebrado. Al final del primer verso hay una ruptura tras el verbo cruzo, por ausencia de un complemento (¿cruzo la calle? ¿cruzo la vida?). Aun suponiendo que no hubiera sido la intención de Vallejo poner la coma final, estaría de todos modos presente la ruptura al leerse "...cruzo/ el traje largo de vestir. Aparece después una nueva ruptura que separa el segundo verso de su complemento preposicional: de la verdad. Quien examine todo el poema encontrará complementos desgajados en los versos 3, 6, 9, 12, 16, 19 y 27 , todos ellos introducidos por de. Sirvan de corroboración los siguientes ejemplos:

7. Cierta guardarropía, sólo ella, nos sabrá a todos en las blancas hojas de las partidas.

14. Tampoco yo descubro a nadie, bajo este mantillo que iridice los lunes de la razón;

Trilce XLIX está estructurado, pues, a base de un ritmo vital discontinuo, como si hubiera pausas de cansancio - ciertamente, no pausas lógicas- entre segmentos de pensamiento, todo to cual consuena con la intención del poema, que es, a nuestro modo de ver, representar una dinámica vital puntuada por desfallecimientos. Lo mismo puede decirse del último verso, pues se da a nuestra conciencia entre dos rupturas y contiene, además, una elipsis, ya que carece de verbo. En suma, la segmentación ilógica y la presencia de vacíos de pensamiento son recursos con que el creador quiso reflejar una estructura interior.

En Trilce XLIX la muerte es sufrimiento, zozobra y total rendición de cuerpo y espíritu, todo ello expresado en una grotesca visión del vacío. Aquí no hay nada dantesco que pudiera dar aterradora grandeza a nuestro fin final, sino una serie de imágenes de agostamiento y vergonzante extirpación. Ni siquiera hay una visión reposada del morir, como la de un Jorge Manrique. Vida y muerte no son más que una labor de cocina, y el mundo, por inferencia, algo así como un caldero, o quizá menos. ¡Ironía de ironías! Las ropas con que el hombre intenta dar dignidad a su actuación terrenal resultan ser falsa iridiscencia. Todo lo que 
hay de tortura y autodenigración en este poema culmina en una serie de imágenes finales del más macabro barroquismo. Difícil es imaginar una visión más desoladora de la vida y destino humanos. La intensidad de Trilce XLIX deja al lector totalmente anonadado.

Muchos modernistas se acercaron al ocaso de su vida con el dolor de quien jamás pudo compaginar los sueños con las realizaciones, pero ninguno llegó a tan desesperanzado convivio con la muerte como Vallejo.

En Trilce se hermanan viejas y nuevas concepciones. Recordando quizá a Marco Aurclio, Vallejo hace del trance final un reposo, un cese total de cuidados y pesadumbres, pero coincide también con Heidegger, al pensar la muerte como una "amenaza," como presencia de una constante imposibilidad. Indicios de esa imposibilidad son las mermas que disminuyen la existencia y matan por fin la voluntad de vida.

Los tres poemas estudiados representan los grados minimo y máximo de la conciencia de derrota que informa a todo el ciclo trílcico. Quizá sea éste el más angustioso de todos los ciclos vallejianos, porque la muerte no tiene para el poeta, en esta etapa de su evolución artística, significado ulterior alguno.

El único de los tres poemas que expresa una débil heroicidad es, como hemos visto, el primero de nuestra serie (Trilce $L X X V$ ), pero, aun aquí, la actitud del creador es la del que siente la berida que aflige a la humanidad y sabe que ésta es inevitable. De los otros dos poemas sc infiere una total inmanencia. El hombre es finito, mortal, "ciego" de nacimiento, y su ser muere con la materia que lo sustenta. El mundo que le rodea es igualmente caduco y contradictorio. Todo en él es cuna y sepultura.

Vistos en conjunto, los tres poemas constituyen una progresiva minoración: lo que es un resignado enfrentarse al dolor en el primer poema es conciencia de futilidad en el segundo $y$, por fin, total derrota en el tercero, tres etapas que se nos dan en tres tonalidades: la profética, la dramática y la trágica.

Ninguno de los poemas señala una vía de escape o la posibilidad de una momentánea trascendencia en el tiempo y, menos aún, el consuelo de un más allá. Vivir es acercarse a la extinción, un progresivo viaje de retorno. Morir es llegar a la Nada.

La nada vallejiana no es el absoluto poético de Mallarmé, esto es, realidad última, libre de contingencias y accidentes, a la que aspira el so- 
ñador con ansias de intemporalidad. Para Vallejo no existe semejante refugio; no hay un limbo poético, sin vida y sin muerte, en que la palabra poética sea presencia y valor supremo.

Vallejo escribió sus poemas trílcicos en años de aguda crisis, y es lógico suponer que el negativismo señalado fuese, por lo menos en parte, reflejo de su desquiciamiento moral. Pero el poeta habría de renacer de sus propias cenizas al forjar más tarde, frente al desastre de la guerra civil española, un programa de vida y una nueva esperanza nutrida por su propia muerte, el humilde "caldo" de Trilce XLIX. El morir no será, en los últimos años de su vida, una degradante reducción y total aniquilamiento sino expresión viril de entereza e inspirada ejemplaridad.

Eduardo Neale-Silva

Iniversity of Wisconsin 